\title{
KEPRIBADIAN EKSTROVERT DAN INTROVERT PADA SISWA KELAS VII G SMP NEGERI 2 PONOROGO PADA PROSES PEMBELAJARAN DALAM PRESPEKTIF PSIKOLOGI SOSIAL
}

\author{
Widya Zulfa Ulwiyah ${ }^{1}$, Muhammad Widda Djuhan ${ }^{2}$ \\ ${ }^{1}$ Institut Agama Islam Negeri Ponorogo \\ zulfalay98@gmail.com \\ ${ }^{2}$ Institut Agama Islam Negeri Ponorogo \\ widdhadjuhan99@gmail.com
}

\begin{abstract}
ABSTRAK
Kepribadian memiliki perbedaan, yakni Ekstrovert dan Introvert. Dengan perbedaan kepribadian yang dimiliki oleh siswa ini, tentunya juga reaksi dan interaksi mereka berbeda pada saat pembelajaran berlangsung. Tujuan dari penelitian ini adalah untuk mengetahui bagaimana interaksi sosial seorang siswa berkepribadian Ekstrovert dengan seorang siswa berkepribadian introvert. Pada saat pembelajaran di ruang kelas sedang berlangsung, ketika menggunakan metode pembelajaran yang berbeda dalam pembelajaran IPS. Dalam penelitian ini, peneliti menggunakan metode penelitian Kualitatif deskriptif yang memiliki karakteristik alami dan mementingkan proses. Pengumpulan data dilakukan dengan menggunakan teknik observasi, wawancara dan dokumentasi. Teknik pengecekan keabsahan data dilakukan dengan trianggulasi waktu. Teknik analisis menggunakan analisis model Miles \& Huberman dengan menggunakan langkah-langkah mereduksi data, penyajian data, dan penarikan kesimpulan. Hasil penelitian menunjukkan bahwa (1) terdapat perbedaan interaksi antara kepribadian ekstrovert dan introvert ketika menggunakan metode pembelajaran dan belajar IPS (2) untuk siswa dengan kepribadian introvert lebih cocok menggunakan metode diskusi, sedangkan kepribadian ekstrovert mampu menyesuaikan diri (3) interaksi sosial tercipta dengan baik dengan demikian sesuai dengan psikologi sosial yang mana mereka mampu berperilaku, berpikir, dalam konteks situasi sosial.
\end{abstract}

Kata Kunci: Kepribadian, Proses Pembelajaran, Komunikasi Sosial

\section{ABSTRACT}

Personality has a difference, namely Extrovert and Introvert. With the different personalities possessed by these students, of course, their reactions and interactions are also different when learning takes place. The purpose of this study was to determine how the social interaction of a student with an extroverted personality with an introverted personality student. When learning in the classroom is taking place, when using different learning methods in social studies learning. In this study, researchers used descriptive qualitative research methods that have natural characteristics and emphasize the process. Data was collected using observation, interview and documentation techniques. The technique of checking the validity of the data is done by time triangulation. The analysis technique uses the analysis of the Miles \& Huberman model by using the steps of reducing data, presenting data, and drawing conclusions. The results showed that (1) there were differences in the interaction between extroverted and introverted personalities when using the social studies learning and learning method (2) for students with introverted personalities to be more suitable to use the discussion method, while extroverted personalities were able to adapt (3) social interactions were created well thus in accordance with social psychology in which they are able to behave, think, in the context of social situations. 


\section{Kepribadian Ekstrovert Dan Introvert Pada Siswa Kelas VII G SMP Negeri 2 Ponorogo Pada Proses Pembelajaran Dalam Prespektif Psikologi Sosial}

Keywords: Personality, Learning Process, Social Communication

\section{PENDAHULUAN}

Kita menjumpai kata "kepribadian" sepanjang waktu. Biasanya, kita berpikir bahwa kepribadian adalah kita sebagaimana adanya; kepribadian adalah identitas diri kita. Bahasa Inggris sendiri memiliki arti yang demikian yang demikian luar biasa untuk memaknainya. Majalah-majalah memberikan kuis-kuis kecil mengenai kepribadian. Mereka juga bahkan mengadakan semacam kontes "gadis berkepribadian". ${ }^{1}$

Menurut Kelly, kepribadian sebagai cara yang unik dari individu dalam mengartikan pengalaman hidupnya. Sebenarnya manusia di dalam kehidupannya sehari-hari tidak selalu membawakan dirinya sebagaimana adanya, melainkan selalu menggunakan tutup muka. Maksudnya adalah untuk menutupi kelemahannya atau ciri-ciri yang khas supaya tindakannya itu dapat diterima oleh masyarakat. Karena dalam kehidupan seharian biasanya orang hanya kan menunjukkan keadaan yang baik-baik saja dan untuk itu maka dipakai sebagai penutupnya. $^{2}$

Kata kepribadian diyakini dari bahasa latin "persona", artinya topeng yang dikenakan oleh para aktor. Dalam psikologi, menurut kamus Webster, kepribadian berarti: (a) totalitas karakteristik individual, terutama berhubungan dengan orang lain (b) suatu kelompok kecenderungan emosi yang terpadu, minat-minat, kecenderungan tingkah laku, dan lain-lain. Termasuk juga kepribadian ganda atau terbelah.

Kebanyakan arti yang popular tercakup dalam satu dari dua penjelasan berikut. Yang pertama menyamakan kepribadian dengan kemampuan dan kecerdasan sosial. Diukur dari pertanyaan seberapa efektifkah seseorang mengeluarkan respons-respons positif terhadap orang yang berbeda-beda dalam berbagai kondisi. Gordon Allport meneliti definisi kepribadian yang digunakan dalam psikologi. Dia menemukan hampir 50 definisi yang berbeda yang berhasil diakategorikan. Salah satu kategori menyebut kepribadian sebagai reaksi orang lain terhadap individu yang menentukan kepribadiannya, kategori lain

1 Lynn Wilcox, Psikologi Kepribadian, (Banguntapan Yogyakarta: Ircisod, 2018) 264-266

2 Dony Sinuraya, "Hubungan Antara Kepribadian Ekstrovert dengan perilaku Agresi Pada Remaja.” Skripsi, Fakultas Psikologi, Universitas Muhammadiyah Surakarta, 2009. 
menjelaskan bahwa kepribadian adalah segala sesuatu yang dianggap penting tentang individu.

Dalam setiap kepribadian memiliki karakteristik tersendiri bagi setiap orang, kemudian banyak dari kalangan kita menyebut ini sebagai kepribadian terbuka (Ekstovert) dan tertutup (Introvert). Di dalam budaya karakter, diri ideal itu serius, disiplin, dan terhormat. Apa yang diperhitungkan bukanlah kesan yang ditampilkan seseorang di muka umum, tetapi lebih pada bagaimana seseorang berperilaku secara pribadi.

Penggolongan tipe kepribadian ekstrovert dan introvert terdapat menggambarkan pola komunikasi dan interaksi sosial setiap individu. Pada, saat berkomunikasi dan berinteraksi dengan orang lain, individu dengan tipe kepribadian ekstrovert adalah individu dengan karakteristik utama yaitu mudah bergaul, implusif, tetapi juga sifat gembira, aktif, cakap dan optimis serta sifatsifat lain yang mengindikasi penghargaan atas hubungan dengan orang lain, sedangkan individu dengan kepribadian introvert adalah individu yang memiliki karakteristik yang berlawanan dengan kepribadian ekstrovert, yang cenderung pendiam, pasif, tidak mudah bergaul, teliti pesimis, tenang dan terkontrol. ${ }^{3}$

Menurut Fromm, karakter manusia berkembang berdasarkan kebutuhan mengganti insting kebinatangan yang hilang ketika mereka berkembang tahap demi tahap. Binatang tingkat rendah sejak lahir hidup diatur oleh instingnya. Bayi manusia, lahir tak berdaya sekaligus dengan insting minimal; jadi manusia harus belajar bagaimana bertingkal laku. Karakter, yang tidak berubah lintas waktu, membuat manusia mampu berfungsi di dunia yang berfungsi di dunia yang terus menerus memberi stimulus, tanpa harus berhenti memikirkan apa yang harus dikerjakan. ${ }^{4}$

Namun dengan datangnya budaya kepribadian, nilai formalitas mulai runtuh, baik untuk pria maupun wanita. Bidang psikologi juga mulai berjuang dengan tekanan untuk menampilkankepercayaan diri. Pada tahun-1920-an seorang psikolog berpengaruh bernama Gordon Allport menciptakan teks diagnosis "kekuasaan-kepatuhan" untuk mengukur dominasi sosial. "Peradaban kita

\footnotetext{
${ }^{3}$ Komang Sri Widiantari, dkk "perbedaan Intensitas Komunikasi melalui jejaring sosial antara tipe kepribadian Ekstrovert dan Introvert pada Remaja.” Jurnal Psikologi Udayana, Vol. 1, No. 1

${ }^{4}$ Alwisol, Psikologi Kepribadian (Malang: UMM Press, 2014), 127
} 


\section{Kepribadian Ekstrovert Dan Introvert Pada Siswa Kelas VII G SMP Negeri 2 Ponorogo \\ Pada Proses Pembelajaran Dalam Prespektif Psikologi Sosial}

sekarang ini," diamati Allport, seorang pemalu penyendiri, "seperti mendewakan pribadi agresif, orang yang penuh semangat."

Menurut Allport, kepribadian adalah organisasi dinamis dalam individu sebagai sistem psikofisis yang menentukan caranya yang khas dalam menyesuaikan diri terhadap lingkungan. Allport menunjukkan keyakinannya, bahwa kepribadian mengantarai individu dengan lingkungan fisis dan lingkungan psikologisnya, kadang-kadang menguasainya. Jadi kepribadian adalah sesuatu yang mempunyai fungsi atau arti adaptasi dan menentukan. ${ }^{5}$

Menurut Murray, kepribadian adalah abastraksi yang dirumuskan oleh teoritisi dan bukan semata-semata deskripsi tingkahlaku orang. Karena rumusan itu didasarkan pada tingkahlaku yang dapat diobservasi dan faktor-faktor yang dapat disimpulkan dari observasi itu. ${ }^{6}$

Namun demikian, kita akan menemukan kebutuhan bahwa kebutuhan untuk tampil percaya diri akan terlihat begitu jelas di dalam konsep baru psikologi yang disebut kompleks inferior. Orang tua yang berniat baik pada pertengahan abad sepakat bahwa sikap pendiam tidak dapat diterima dan sikap senang berbaur ideal untuk anak perempuan dan laki-laki. Sebagian melarang anak mereka untuk berdiam diri dan memiliki hobi serius, seperti musik klasik, yang tidak membuat mereka populer. Mereka menyekolahkan anak-anak mereka sedini mungkin, yang tugas utamanya adalah belajar bersosialisasi.

Adler memberi tekanan kepada pentingnya sifat khas (unik) kepribadian, yaitu individualitas, kebetulan serta sifat-sifat pribadi manusia. Menurut Adler tiap orang adalah suatu konfigurasi motif-motif, sifat-sifat, serta nilai-nilai yang khas; tiap tindak yang dilakukan oleh seseorang membawakan corak khas gaya kehidupannya yang bersifat individual. ${ }^{7}$

William Whyte pengarang The organization Man, buku terlaris tahun 1956, menjabarkan bagaimana orang tua dan guru berkonspirasi untuk memperbaiki kepribadian anak pendiam. Orang tua yang terjebak dengan sistem nilai seperti ini

${ }^{5}$ Sumadi Suryabrata, Psikologi Kepribadian (Jakarta: PT Rajagrafindo Persada, 2016), 205-207

${ }^{6}$ Alwisol, Psikologi Kepribadian (Malang: UMM Press, 2014), 179

${ }^{7}$ Sumadi Suryabrata, Psikologi Kepribadian (Jakarta: PT Rajagrafindo Persada, 2016), 
bukanlah orang tua yang buruk atau bodoh, mereka hanya menyiapkan anak-anak mereka untuk menghadapi dunia nyata. ${ }^{8}$

Harry Stack Sullivan mengatakan bahwa kepribadian adalah pola yang relatif menetap dari situasi-situasi antar pribadi yang berulang, yang menjadi ciri kehidupan manusia. Kepribadian itu konstruk hipotesis yang hanya dapat diamati dalam konteks interpersonal. Sepanjang hayat setiap orang bergerak dalam lingkungan sosial, sejak bayi sudah terlibat dalam interaksi dengan orang lain. Bahkan ketika orang sendirian pun orang lain muncul dalam pikiran, perasaan, dan fantasinya. Sullivan tidak menyangkal pentingnya hereditas dan pematangan dalam membentuk dan membangun kepribadian. Namun ia berpendapat apa yang khas manusiawi adalah interaksi sosial. Pengalaman hubungan antar pribadi telah berubah fungsi fisiologik organisme (sehingga manusia kehilangan kesatuan biologiknya) menjadi organisme sosial, bahkan sosialisasi telah merubah proses biologiknya yang paling mendasar (bernafas, pencernaan, eliminasi). Psikiatri tidak dapat dipisahkan dari psikologi sosial. ${ }^{9}$

Secara singkat, kita ingin bergabung dan berhubungan dengan orang lain, kita ingin mengendalikan dan dikendalikan, serta kita ingin mencintai dan dicintai. Kebutuhan sosial ini hanya dapat dipenuhi dengan komunikasi interpersonal yang efektif. Dewasa ini para ilmuan, filsuf dan ahli agama yang sering berbicara tentang alienasi-merasa terasing, kesepian dan kehilangan keakraban pada manusia moderen. ${ }^{10}$

Ada banyak teori yang membahas tentang kepribadian. Salah satunya adalah tipe kepribadian ekstrovert dan introvert. Istilah ekstrovert dam introvert pertama kali dipakai oleh Carl Gustav Jung. Jung berpendapat bahwa pada setiap diri seseorang terdapat keseimbangan antara dorongan-dorongan kepribadian yang berlawanan. Kepribadian seseorang me;iputi ekstrovert dan introvert, rasional dan irasional, laki-laki dan perempuan, kesadaran dan ketidak sadaran serta didorong oleh kejadian-kejadian di masalalu yang ditarik oleh harapan-harapan di masa depan. $^{11}$

\footnotetext{
${ }^{8}$ Susan Chain, Quiet, Kekuatan Introver di dalam Dunia yang Tidak Bisa Berhenti Bicara (Yogyakarta: ANDI, 2013), 27-35

${ }^{9}$ Alwisol, Psikologi Kepribadian (Malang: UMM Press, 2014), 147

10 Jalaluddin Rakhmat, Psikologi Komunikasi (Bandung: Simbiosa Rekatama Media,

${ }^{11}$ Sri Wiji Lestari,"Analisis proses berpikir kritis siswa dalam pemecahan masalah matematika pada pokok bahasan himpunan ditinjau dari tipe kepribadian ekstrovert dan
} 2018), 18 


\section{Kepribadian Ekstrovert Dan Introvert Pada Siswa Kelas VII G SMP Negeri 2 Ponorogo Pada Proses Pembelajaran Dalam Prespektif Psikologi Sosial}

Dalam lingkup lingkungan sekolah tentunya juga memiliki beberapa kepribadian berbeda, salah satunya adalah siswa mereka beberapa individu yang memiliki perbedaan. Perbedaan ini yang tidak dapat dihindari di antara setiap individu siswa, antara lain mencakup dalam minat, motivasi, dan kepribadian. Ketiga faktor psikologis ini berkorelasi dalam tujuan belajar siswa di dalam kelas. Ketika faktor psikologis ini berkorelasi positif, dalam belajar mengajar tentunya membutuhkan hal yang disebut dengan interaksi dan komunikasi. Keaktifan siswa dalam proses pembelajaran IPS yakni berusaha mencari tahu informasi tentang materi yang sedang di bahas. Dan bertanya apabila ada kesulitan dengan meteri tersebut, bertanya bisa ditujukan pada teman atau pun guru pengajar.

Akan tetapi rendahnya komunikasi sosial siswa, seperti tidak senang bergaul dengan teman sekelasnya menimbulkan problematika pembelajaran dalam diri siswa tidak terselesaikan sehingga kesulitan dalam pembelajaran. Oleh karena itu seorang anak setidaknya memiliki sikap dan sifat luwes dalam melakukan interaksi dan berkomikasi terlebih dalam lingkup pergaulan teman sebaya. Sehingga ada orang lain yang turut membantu dalam menyelesaikan kesulitan pelajaran. Kemauan siswa untuk melontarkan pertanyaan dan menjawab pertanyaan, menunjukkan bahwa siswa tersebut aktif dan tidak pemalu, serta dapat melakukan interaksi sosial dengan baik, beberapa ciri tersebut menunjukkan bahwa siswa mempunyai kepribadian ekstrovert. Sedangkan, sebaliknya. Ketika seorang siswa memilih diam dan tidak mau melontarkan pertanyaan mau pun tidak menjawab pertanyaan dari guru, menunjukkan bahwa siswa tersebut menujukkan ciri mempunyai kepribadian introvert.

Berdasarkan respon keaktifan siswa yang berbeda pada pembelajaran yang sedang berlangsung di dalam kelas ketika proses belajar IPS yang dimana faktor model pembelajaran yang sedang disampaikan guru juga berpengaruh terhadap pembelajaran IPS di dalam kelas. Seperti menjelaskan materi secara abstrak, hafalan materi dan ceramah dengan komunikasi satu arah, dan masih di dominasi oleh pengajar. Sehingga kondisi pembelajaran seperti inilah menjadikan pembelajaran berlangsung kurang menyenangkan, dan potensi keaktifan siswa berkurang. Sehingga siswa dengan kepribadian ektrovert memilih sibuk sendiri dan tidak memperhatikan pelajaran. Begitu pula ketika ketika pengajar 
memberikan pertanyaan untuk pembelajara, siswa dengan kepribadian introvert akan lebih memilih diam.

Berdasarkan hasil observasi awal yang dilakukan oleh peneliti terkhusus pada kepribadian dan interaksi sesama siswa kelas VII G di SMP Negeri 2 Ponorogo. Dalam kegiatan belajar mengajar, tentu respon seorang anak akan berbeda dengan seorang anak yang lain. Mereka memiliki ciri tersendiri dalam mengespresikan cara belajar secara tidak langsung. Dapat diamati bagaimana reaksi mereka ketika sedang dalam suasana belajar, perbedaan mencolok terlihat ketika mengamati mereka. Yaitu kepribadian siswa ekstrovert dan kepribadian siswa Introvert. Siswa atau seorang anak yang memiliki kepribadian ekstrovert cenderung aktif dalam kegiatan, kepercayaan diri mereka tinggi, berinteraksi dengan baik, aktif bertanya dan menjawab, berpikir secara objectif. Sedangkan siswa atau seorang anak yang berkepribadian introvert, cenderung lebih pasif. Kurang aktif bertanya dan menjawab, kepercayaan diri mereka sedikit lebih rendah, berikir secara subjectif. ${ }^{12}$

Perbedaan tersebut sedikit banyak berpengaruh pada cara belajar dan interaksi belajar di dalam kelas. Berbeda kepribadian mereka berbeda pula cara belajar mereka, berbeda kepribadian mereka berbeda pula cara berpikir mereka. Dengan demikian pengajar berusaha memberikan kenyamanan dalam proses pembelajaran, sehingga dari masing-masing mereka dapat bekerja sama dengan baik. Adanya perbedaan kepribadian siswa juga berpengaruh bagaimana cara mereka berinteraksi sosial, cara mereka melakukan respon terhadap lingkungan sekitar, melakukan hal dalam sudut pandang mereka terhadap orang lain, bersimpati dalam suatu hal. siswa tentu memiliki rasa empati yang berbeda pula, kepekaan mereka juga berbeda.

Kepribadian ekstrovert akan cenderung menyuarakan pendapatnya, menyukai perhatian orang lain dan lebih memilih bercampur pada suatu kelompok sebab kepercayaan diri mereka lebih meningkat. Sehingga mereka akan melakukan apapun yang menjadi keyakinan mereka. Kepribadian introvert akan cenderung berpikir ulang sebelum menyuarakan pendapat, tampak ragu, tidak begitu menyukai kebisingan, dan tidak terlalu menyukai keramaian. Mereka dapat berpendapat dengan leluasa ketika kondisi lingkungan sekitarnya ia yakini

${ }^{12}$ Bedasarkan hasil observasi di dalam kelas VII G SMP Negeri 2 Ponorogo, 17 Maret 


\section{Kepribadian Ekstrovert Dan Introvert Pada Siswa Kelas VII G SMP Negeri 2 Ponorogo Pada Proses Pembelajaran Dalam Prespektif Psikologi Sosial}

menguntungkan. Beberapa orang mungkin akan sulit memahami apa yang mereka maksudkan, akan tetapi seorang introvert lebih menyusun kata sebelum menjadi kalimat.

Seorang siswa berkepribadian ekstrovert akan bersemangat ketika pengajar memberi implus pertanyaan, mereka kompetitif. Begitu sebaliknya dengan siswa berkepribadian introvert, mereka akan cenderung mengalah dan menunggu untuk ditunjuk menjawab pertanyaan tersebut. Akan tetapi, ketika metode diskusi dlakukan oleh pengajar. Hubungan mereka terlihat lebih saling mendukung, tidak lagi kompetitif dan membelakangi satu sama lain. Siswa berkepribadian ekstovert akan menuntun siswa berkepribadian intovert dalam memahami sebuah materi yang sedang di diskusikan. Interaksi sosial mereka tampak tidak terjadi kesenjangan. Oleh karena itu, peneliti tertarik untuk mengkaji dan memahami lebih jauh lagi tentang kepribadian siswa saat berinteraksi sebagai objek kajian pemenuhan tugas akhir dengan mengangkat judul: "Kepribadian Ekstovert dan Introvert Pada Siswa Kelas VII G SMP Negeri 2 Ponorogo Pada Proses Pembelajaran Dalam Prespektif Psikologi Sosial”

\section{METODE PENELITIAN}

Dalam penelitian ini, digunakan pendekatan penelitian kualitatif, metode penelitian kualitatif merupakan suatu cara yang digunakan untuk menjawab masalah penelitian yang berkaitan dengan data berupa narasi yang bersumber dari aktivitas wawancara, pengamatan, pengalian dokumen. ${ }^{13}$ Pendekatan ini dipilih karena, dalam pengumpulan data di kelas VII G SMP Negeri 2 Ponorogo dengan menggunakan wawancara dan pengamatan. Dan jenis penelitian yang digunakan dalam penelitian ini adalah deskriptif kualitatif. Peneliti berusaha memahami serta memaknai pandangan serta kejadian pada subjek penelitian dalam rangka menggali tentang penyebab, bentuk-bentuk, dampak, dan strategi maupun upaya dalam menangani perilaku siswa dengan dua jenis kepribadian yang berbeda dalam proses pembelajaran IPS di dalam kelas.

Berdasarkan penilitian yang akan diteliti maka peniliti menggunakan jenis penelitian studi kasus pada penelitian ini. Meriam dan Tisdell mendefinisikan studi kasus sebagai deskripsi dan analisis mendalam dari bounded System. Yin

${ }^{13}$ Wahidmurni, "Pemapamaran Metode Kualitatif," Dosen Fakultas Tarbiyah dan Keguruan, UIN Maulana Malik Ibrahim Malang, (Juli, 2014) 
mendefinisikan studi kasus sebagai proses penelitian, sebuah studi kasus penelitian bertujuan untuk menguji pertanyaan dan masalah penelitian, yang tidak dapat dipisahkan antara fenomena dan konteks di mana fenomena tersebut terjadi. ${ }^{14}$ Penelitimemilih studi kasus dengan alasan bahwa peneliti ini lebih sesuai untuk mendeskripsikan bagaimana perilaku interaksi antara dua kepribadian berbeda siswa sehingga mengganggu tujuan pembelajaran IPS yang sedang berlangsung, dan untuk mengungkap dan menjelaskan penyebab hal tersebut. Sehingga hasil penelitian ini dapat dijadikan sebagai sumber pengetahuan baru sehingga guru dapat melakukan pembelajaran IPS dengan menyenangkan di dalam kelas serta memberikan solusi tepat.

Teknik pengumpulan data merupakan langkah yang paling utama dalam penelitian, karena tujuan utama dari penelitan adalah mendapatkan data. Dalam penelitisn kualitatif, pengumpulan data dilakukan pada natural setting (kondisi yang alamiah), sumber data primer., dan teknik pengumpulan data lebih banyak pada observasi berperanserta (participan observation), wawancara mendalam dan dokumentasi.

1. Teknik Observasi

Menurut Sukmadinata, menyatakan bahwa observasi atau pengamatan merupakan suatu teknik atau cara mengumpulkan data dengan jalan mengadakan pengamatan terhadap kegiatan yang sedang berlangsung. Kegiatan tersebut bisa berkenaan dengan cara guru mengajar, siswa belajar, kepala sekolah yang sedang memberikan pengarahan, dan sebagaianya. Observasi dapat dilakukan secara partisipatif ataupun nonpartisipatif. Dalam observasi partisipatif, pengamat ikut serta dalam kegiatan yang sedang berlangsung, sedangkan observasi nonpartisipatif pengamat tidak ikut serta dalam kegiatan. ${ }^{15}$

Observasi dalam penelitian ini dilakukan menggunakan observasi partisipatif. Peneliti melakukan pengamatan juga melakukan apa yang dilakukan oleh narasumber, maka diharapkan data yang diperoleh akan lebih lengkap, tajam, dan mengetahui singkat makna setiap perilaku yang tampak. Observasi ini dilakukan ketika pembelajaran IPS sedang berlangsung di dalam

\footnotetext{
${ }^{14}$ Unika Prihat Santi, "Menggunakan Studi Kasus sebagai Metode Ilmiah Dalam Psikologi" Buletin Psikologi, 2, 128

15 Hardani dkk, Metode Penelitian Kualitatif dan Kuantitatif ( Yogyakarta; Pustaka Ilmu, 2020), 124-125
} 


\section{Kepribadian Ekstrovert Dan Introvert Pada Siswa Kelas VII G SMP Negeri 2 Ponorogo Pada Proses Pembelajaran Dalam Prespektif Psikologi Sosial}

kelas, serta kepada siswa maupun guru guna mendapatkan data terkait dengan interaksi kepribadian ekstrovert dan introvert pada siswa ketika pembelajaran berlangsung.

\section{Teknik Wawancara}

Wawancara adalah percakapan dengan maksud tertentu. Percakapan itu dilakukan oleh dua pihak yaitu pewawancara yang mengajukan pertanyaan dan terwawancara yang memberiah wawancara yang bebas dimana peneliti tidak menggunakan pedoman wawancara yang telah tersusun secara sistematis dan lengkap untuk pengumpulan datanya. Pedoman wawancara yang digunakan hanya berupa garis-garis besar persalahan yang ditanyakan. ${ }^{16}$

Wawancara yang terstruktur dipilih oleh peneliti sebagai teknik pengumpulan data, karena informasi yang didapatkan oleh peneliti telah diketahui secara pasti oleh peneliti. Karena itu dalam melakukan wawancara, pengumpul data atau peneliti telah mempersiapkan instrumen pertanyaan dan alternatif jawaban. ${ }^{17}$

Dalam pengumpulan data dengan teknik wawancara ini, wawancara difokuskan kepada guru-guru kelas yang mengajar di kelas VII G SMP Negeri 2 Ponorogo guna memperoleh informasi tentang bagaimana pembelajaran IPS sedang berlangsung di dalam kelas, serta kepada siswa maupun guru guna mendapatkan data terkait dengan interaksi kepribadian ekstrovert dan introvert pada siswa ketika pembelajaran berlangsung, serta bagaimana guru menangani perbedaan tersebut, dan hal apa saja yang menghambat serta mendukung upaya guru tersebut.

3. Teknik Dokumentasi

Dokumen merupakan catatan peristiwa yang sudah berlalu. Dokumen bisa berbentuk tulisan, gambar, atau karya-karya monumental dari seseorang. Dokumenyang berbentuk tulisan misalnya catatan harian, sejarah kehidupan (life histories), ceriter, biografi, peraturan, kebijakan. Dokumen yang berbentuk gambar, misalnya foto, gambar hidup, sketsa, dan lainlain.Keuntungan menggunakan dokumentasi ialah biayanya relative murah, waktu dan tenaga lebih efisien.

\footnotetext{
${ }^{16}$ Sugiyono, Metode Penelitian Pendidikan Pendekatan Kuantatif, Kualitatif, dan $R \& D$ (Bandung:Alfa Beta, 2015) 320-321

${ }^{17}$ Sugiyono, Metode Penelitian Pendidikan Pendekatan Kuantatif, Kualitatif, dan $R \& D$ (Bandung:Alfa Beta, 2015) 233
} 
Studi dokumentasi yang dilakukan dalam penelitian ini adalah dokumentasi berupa letak geografis SMP Negeri 2 Ponorogo, sejarah berdirinya SMP Negeri 2 Ponorogo, visi dan misi SMP Negeri 2 Ponorogo, struktur organisasi SMP Negeri 2 Ponorogo, data pendidik SMP Negeri 2 Ponorogo, data peserta didik SMP Negeri 2 Ponorogo, daftar sarana dan prasarana SMP Negeri 2 Ponorogo, kondisi pembelajaran, serta kegiatan yang berkaitan dengan upaya guru dalam menangani kepribadian ekstrovert dan introvert pada siswa ketika pembelajaran berlangsung.

Analisis data kualitatif adalah upaya yang dilakukan dengan jalan bekerja dengan data, mengorganisasikan data, memilah-milahnya menjadi satuan yang dapat dikelola, mensistesiskannya, mencari dan menemukan pola, menemukan apa yang pennting, dan apa yang dipelajari, dan memutuskan apa yang dapat diceritakan kepada orang lain. ${ }^{18}$

Teknik analisis data yang digunakan dalam penelitian ini adalah menggunakan analisis selama di lapangan meodel Miles and Huberman. Yang mengemukakan bahwa analisis data dalam penelitian kualitatif, dilakukan pada saat pengumpulan data berlangsung, dan setelah selesai pengumpulan data dalam periode tertentu. Aktivitas dalam analisis data, yaitu datareduction, datadisplay, dan conclusion drawing/verivication.

\section{HASIL DAN PEMBAHASAN}

\section{A. Analisis data tentang kepribadian Introvert dan Ekstrovert siswa kelas} VII G SMP Negeri 2 Ponorogo pada proses pembelajaran IPS.

Pembelajaran maksudnya adalah seperangkat tindakan yang dirancang untuk mendukung proses belajar peserta didik, dengan memperhitungkan kejadian-kejadian eksternal yang berperan terhadap rangkaian kejadiankejadian eksternal yang berperan terhadap rangkaian kejadian-kejadian internal yang berlangsung di dalam peserta didik. ${ }^{19}$ Dalam pembelajaran tentunya melibatkan banyak orang, dan tempat orang banyak berkumpul disebut Lingkungan.

${ }^{18}$ Lexy J. Moleong, Metodologi Penelitian Kualitatif (Bandung; PT. Remaja

${ }^{19}$ Fakhrurrazi, "Hakikat Pembelajaran Yang Efektif" Jurnal At-tafkir, Vol. 11, 2, (1 Juni 2018) 86 
Menurut Abu Ahmadi, Ilmu Pengetahuan Sosial ialah ilmu-ilmu sosial yang dipilih dan disesuaikan bagi penggunaan program pendidikan di sekolah atau bagi kelompok belajar lainnya yang sederajat. Menurut Ali Imran udin Ilmu Pengetahuan Sosial (IPS) ialah ilmu-ilmu sosial yang disederhanakan untuk tujuan-tujuan pendidikan dan pengajaran di sekolah dasar dan menengah. IPS ialah bidang studi yang merupakan paduan dari sejumlah disiplin ilmu sosial. Dari beberapa pendapat di atas, dapat disimpulkan bahwa materi IPS diambil dari berbagai disiplin ilmu sosial seperti geografi, sejarah, sosiologi, antropologi, psikologi sosial, ekonomi, ilmu politik, ilmu hukum dan ilmu-ilmu sosial lainnya yang dijadikan sebagai bahan baku bagi pelaksanaan program pendidikan dan pengajaran di sekolah dasar dan menengah. ${ }^{20}$

Dengan demikian IPS adalah perpaduan dari berbagai ilmu sosial termasuk psikologi sosial, yang mana di dalamnya juga terdapat bagaimana seseorang dapat melakukan interaksi dan berkomunikasi pada lingkungan sekitar. Begitu pula dalam lingkup sekolah, tentunya melibatkan diri pada lingkungan sekitar dengan berkomunikasi dan berinteraksi. Terutama pada lingkungan antara guru dan siswa, serta siswa dengan sesamanya. Interaksi mereka terjalin ketika sedang melakukan pembelajaran di dalam kelas.

Lingkungan menurut Webster's New Collegiate Dictionary diterangkan sebagai "the aggregate of all the external conditions and influences affecting the life and development of an organism" atau diartikan sebagai kumpulan segala kondisi dan pengaruh dari luar terhadap kehidupan dan perkembangan suatu organisme. Lingkungan dalam pengertian umum, berarti situasi yang ada di sekitar manusia. ${ }^{21}$ Berdasarkan pengamatan yang dilakukan oleh peneliti, ketika proses pembelajaran berlangsung di lingkungan kelas, siswa VII G yang memiliki kepribadian Ekstrovert mempunyai kecenderungan menyukai jenis pembelajaran yang menggunakan gerak tubuh dan proses berpikir secara bersamaan. Pemahaman mereka akan sangat terbantu saat pengajar atau guru menggunakan metode pembelajaran seperti diskusi. Akan tetapi, bagi para siswa Introvert hal tersebut membuat diri mereka semakin

\footnotetext{
${ }^{20}$ Silvia Tabah Hati, "Hubungan Antara Ilmu-ilmu Sosial dan IPS” Ijtimaiyah, Vol. 2, 1, ( Januari-Juni 2018) 3

21 Fadilaturrahmi, "Lingkungan Belajar Efektif Bagi Siswa Sekolah Dasar" Basicedu, 2, (2018) 61-69
} 
meredup. Sebab mereka kurang memiliki kepercayaan diri yang baik, sehingga berakhir menunggu sampai sang guru untuk menjawab pertanyaan.

Pada saat guru memulai pembelajaran IPS dengan metode pembelajaran ceramah, siswa dengan kepribadian ekstrovert akan memilih menyibukkan diri sendiri dan tidak memperhatikan guru yang sedang menyampaikan materi di depan kelas. Dengan dalih mereka merasa bodan dengan suasana pembelajaran, dan tentunya menganggu konsentrasi pembelajaran. Sehingga menimbulkan kurangnya pemahaman terhadap materi yang telah disampaikan dan menghambat tersampaikannya materi dengan sempurna. Begitu pula ketika guru sedang mengajukan pertanyaan mengenai materi yang sedang disampaikan sebelumnya, siswa dengan kepribadian introvert akan.

Siswa berkepribadian Introvert menutup diri mereka sebab kurangnya kepercayaan diri sehingga sedikit banyak mengalami ketertinggalan dalam konteks pelajaran yang sedang disampaikan. Mereka cenderung sedikit bersuara ketika pengajar memberikan kuis atau pun saat mempresentasikan hasil diskusi. Selain itu, mereka tidak langsung mengerti dengan apa yang sedang guru perintahkan padanya, sehingga materi yang disampaikan terhambat. Kepercayaan diri mereka semakin surut jika tidak mendapatkan dukungan dari sekitar. Jadi pada kelas VII G, guru memberikan implus, memberikan sugesti agar murid dengan kepribadian tersebut dapat memupuk lagi kepercayaan dirinya.

Selain memiliki sedikit kepercayaan diri, siswa berkepribadian introvert akan menyusun apapun yang akan disampaikan sebelum mengungkapkannya di depan umum. Sehingga dengan begitu dia akan lebih percaya diri dalam menyampaikan perihal pelajaran yang menjadi tugasnya di depan kelas. Dukungan dari teman sekelas membuat mereka lebih mampu berbicara dengan baik, selain saling mendukung siswa dengan kepribadian Ekstrovert juga sangat terbantu ketika diskusi sedang berlangsung. Mereka mengakui anak dengan kepribadian Introvert sangat baik dalam mengerjakan dan berkonsentrasi ketika sedang mengerjakan bersama. Mereka juga lebih nyaman dengan bekerja sendiri, yang mana menggunakan metode pembelakaran bersifat pasif atau konvensional. Mereka mengalami peningkatan dalam pembelajaran. 
Anak atau seseorang dengan kepribadian introvert lebih melibatkan perasaan ketika sedang berinteraksi di lingkungan sosial atau pun ketika sedang mengerjakan sesuatu untuk disampaikan pada mata umum. Baginya, kesempurnaan sesuatu harus menjadi hal utama yang harus dipenuhi. Apabila hal tersebut gagal dia lakukan maka perasaan menghakimi diri sendiri lalu berkurangnya rasa percaya diri akan timbul. Sehingga ia pun memiliki rasa obsesi yang besar pada sesuatu yang dianggapnya sangat serius, sampai apa yang nanti akan ia sampaikan harus dalam kriteria sempurna.

Jika sesuatu tersebut dapat ia percaya dan ia kategorikan sempurna, maka kegugupan yang akan dialami bisa ia kendalikan sebaik mungkin. Begitu pula yang dialami oleh anggota kelas VII G, seseorang dari mereka melakukan dan mempersiapkan diri sebaik mungkin agar dapat menyampaikan gagasan maupun hasil kerja kelompok yang akan disampaikan di depan kelas. Dia menyampaikan sesuai dengan apa yang telah dipersiapkan sebelumnya. Suport dari rekan setimnya juga membangun kepercayaan dirinya hingga kemudian dapat berbicara dengan baik sesuai dengan rencana.

Seorang introvert memang memiliki rasa gugup tinggi dan kepercayaan diri rendah, akan tetapi hal tersebut dapat dengan mudah teratasi dengan dukungan lingkungan sosial sekitarnya. Dukungan tersebut, telah diciptakan para siswa dengan kerja sama kelompok dari hasil bentukan guru membuat kelompok belajar di dalam kelas. Lantas siswa dengan kepribadian tersebut memiliki perasaan senang dan mengikuti pembelajaran dengan baik.

Lawan dari kepribadian introvert adalah ekstrovert, dimana siswa dengan kepribadian terbuka lebih memiliki kepercayaan diri tinggi. Sehingga ketika guru memberikan implus pertanyaan pada personal, mereka bersemangat dan bersaing mendapatkan perhatian guru sehingga ia mendapatkan nilai tambahan sesuai dengan apa yang dijanjikan sebelumnya. Mereka lebih menyukai pembelajaran yang melibatkan objek dan benda dipergunakan guru untuk menerangkan materi yang sedang dipelajarai bersama. Siswa dengan kepribadian terbuka cenderung akan menampakkan eksistensi kepeduliannya jika teman atau sekelilingnya belum memahami apa yang sedang disampaikan guru di depan kelas.

Berdasarkan hasil wawancara yang dilakukan oleh peneliti, dalam lingkungan kelas VII G SMP Negeri 2 Ponorogo siswa memiliki rasa 
komunikasi baik antara sesama taman atau pun dengan guru, mereka dapat membangun relasi baik dalam berinteraksi sosial maupun ketika kegiatan belajar sedang berlamgsung. Pada dasarnya dilihat dari karakter kepribadian ekstrovert yang memilih lebih kompetitif dan terkadang cenderung tidak memperhatikan sekitar, lain halnya dengan anggota kelas VII G mereka memiliki kerja sama yang bagus. Saling membantu dalam memberikan penjelasan materi yang telah disampaikan oleh guru pada teman yang belum mengerti akan materi tersebut.

Seperti yang dikemukakan oleh Chaplin dalam Naisaban, ekstrovert adalah suatu kecenderungan yang mengarahkan kepribadian yang lebih banyak ke luar dari pada ke dalam diri sendiri. Seorang ekstrovert mempunyai sifat sosial, lebih banyak berbuat daripada berkontenplasi (merenung dan berpikir). Seorang yang ekstrovert juga adalah orang yang penuh motif-motif yang dikoordinasi oleh kejadian-kejadian eksternal. Ekstrovert adalah sebuah sikap yang menjelaskan aliran psikis kearah luar sehingga orang yang bersangkutan akan memiliki orientasi objektif dan menjauh dari subjektif. Ekstrovert akan lebih mudah dipengaruhi oleh lingkungan sekeliling di bandingkan oleh kondisi sendiri. Individu ekstrovert cenderung berfokus pada sikap objektif dan menekankan sisi subjektifnya. ${ }^{22}$

Demikian pula yang terjadi pada siswa dan siswi kelas VII G SMP Negeri 2 Ponorogo, mereka cenderung memiliki perilaku mudah dalam menyampaikan pendapat atau pun intuisi dari dalam pemikiran masingmasing. Ketika proses belajar mengajar mereka sedang berlangsung, menimbulkan suasana lingkungan yang tentunya berubah-ubah sesuai dengan pembawaan kelas oleh guru mata pelajaran. Sehingga suasana hati dan pikiran mereka juga akan memiliki sudut pandang sendiri. Sehingga, ketika suasana lingkungan belajar mereka menyenangkan maka ia akan merasa bersemangat dan tentunya menciptakan keadaan interaksi aktif, namun sebaliknya ketika suasana menjadi tidak menyenangkan maka mereka akan melampiaskaannya dengan membuat pertanyaan untuk ditanyakan pada guru setelah penyampaian materi berlangsung.

22 Mohamad Fajar kurniawan,"Perilaku Pro-sosial Ditinjau dari tipe kepribadian Introvert dan Ekstrovert (studi pada mahasisa) .", skripsi, Jurusan Psikologi Fakultas Ilmu pendidikan Universitas negeri semarang, 2016 
Kebanyakan dari siswa berkepribadian ekstrovert memiliki standart kepuasan tinggi dalam memahami suatu materi pelajaran, sehingga mereka tidak akan berhenti melakukan pertanyaan dan mencatat jawaban sebelum puas dan memahami sepenuhnya tentang materi pelajaran tersebut. Kemudian membagi pemahaman yang dia peroleh kepada teman yang belum begitu memahami penjelasan dari guru. Melakukan sesuai dengan perolehan pemahaman dari guru, mereka akan cenderung berkelompok untuk mempermudah dalam menjelaskan apa yang ia pahami kepada teman-teman.

Di luar kegiatan pembelajaran dalam kelas, para ekstrovert cenderung memilih berkecimpung pada keramaian atau lebih memilih pada suasana ramai dan menjadi pusat perhatian. Mereka akan cenderung menjadi pasif atau kebosanan jika di hadapkan pada sesuatu yang cenderung tidak melibatkan keramaian. Kemudian lebih menyukai sesuatu yang melibatkan interaksi dalam skala besar, yaitu pada saat mereka menempatkan diri pada suatu komunikasi antar sesama dan lingkup lingkungan atau pun di luar lingkungan sosial.

Suasana interaksi antara siswa berkepribadian ekstrovert dengan siswa berkepribadian introvert memiliki hubungan baik, anggota kelas VII G memiliki sifat saling membantu baik dalam konteks belajar di kelas maupun di luar kegiatan tersebut. Mereka gemar membantu rekan belajarnya untuk dapat lebih memahami materi pembelajaran yang sedang berlangsung. Sebab guru juga mengajarkan bahwa saling bekerja sama mampu menyelesaikan permasalahan dalam materi pembelajaran.

\section{B. Analisis data tentang perbedaan kepribadian Ekstrovert dan Introvert siswa kelas VII G SMP Negeri 2 Ponorogo pada proses pembelajaran tahun ajaran 2019/2020 dalam prespektif psikologi sosial.}

Menurut Jung, individu dengan tipe kepribadian Ekstovert mempunyai karakteristik lebih ekspresif dalam menyampaikan setiap emosi yang dirasakannya, sehingga hal tersebut membuat orang dengan tipe Ekstovert akan lebih mudah untuk mengekspresikan setiap emosi yang dirasakan dengan cara menjalin komunikasi. Jung juga menjelaskan bahwa pada dasarnya individu dengan tipe kepribadian Introvert cenderung lebih menyukai aktivitas 
yang tidak melibatkan orang-orang disekitanya dan memberikan perhatian lebih berpusat pada diri sendiri.

Dari hasil observasi dan wawancara peneliti, Siswa dengan kepribadian terbuka lebih menikmati suasana ramai atau semua perhatian berpusat padanya, begitu pula dengan siswa kelas VII G mereka yang memiliki kepribadian terbuka atau ekstrovert akan sangat mudah ketika mengespresikan diri dalam waktu pembelajaran di dalam kelas sedang berlangsung. Dia akan merasa bosan dan teralihkan konsentrasi ketika pembelajaran berlangsung monoton, hanya mengandalkan metode ceramah oleh guru pengajar. Justru, dengan melibatkan keaktifan gerak mereka, seperti menggunakan metode belajar diskusi, presentasi, dan lain sebagainya. Rasa bosan mereka akan terkikis dengan melakukan kegiatan tersebut.

Ada beberapa bagian yang mempengaruhi kegiatan atau proses belajar mengajar, yang sering disebut dengan faktor eksternal dan faktor internal. Faktor eksternal adalah diantaranya guru, sarana prasarana, metode pembelajaran, kurikulum dan lingkungan belajar yang efektif dan menyenangkan. Faktor internal diantaranya, motivasi, gaya belajar, tipe kepribadian, kecerdasan gaya berpikir dan lain sebagainya.

Siswa dengan kepribadian introvert cenderung nyaman dengan sedikitnya atensi yang didapatkan, sehingga ketika pembelajaran IPS dengan metode ceramah berlangsung, dia lebih fokus dengan penjelasan guru di depan kelas. Akan tetapi siswa dengan kepribadian ekstrovert akan berkurang fokus sebab mereka merasa bosan dengan pembelajaran yang sedang berlangsung. Karena menyadari hal demikian, guru berusaha menghidupkan kembali dengan memberikan beberapa pertanyaan acak dan sesuai materi yang telah diajarkan sebelumnya.

Selain dengan rasa bosan yang menghilang, interaksi dalam kegiatan belajar mengajar terjalin dengan sangat baik. Sehingga di antara kedua kepribadian tersebut dapat terjalin dengan baik, tidak menimbulkan tenggang rasa serta diskriminasi antar teman. Di balik itu semua, guru menyokong semangat mereka dengan memfasilitasi kebutuhan belajar mereka. Demikian kebutuhan belajar terpenuhi, gairah kessenangan mereka dalam menekuni materi semakin bertambah. 
Berdasarkan hasil wawancara yang dilakukan oleh peneliti, siswa kelas VII G yang memiliki kepribadian ekstrovert dengan kecenderungan mereka bersikap pada lingkungan belajar atau di luar kelas siswa tersebut memiliki kreatifitas tersendiri dalam melakukan sebuah interaksi. Seperti saat ketika sedang dalam kegiatan belajar mengajar mereka berkeingintahuan yang tinggi sehingga membuat diri mereka menonjol. Lewat kreatifitas mereka ketika sedang berdiskusi atau pun menjalin relasi untuk belajar antar teman, dengan berani berinovasi dengan tugas yang di berikan oleh guru ketika berdiskusi. Karena sikap tersebut siswa akan lebih dikenal oleh guru pengajar.

Para ekstrovert lebih suka menonjolkan diri atau lebih memilih di kenal banyak orang, sehingga mereka akan lebih percaya diri dalam berinteraksi. Oleh sebab itu para ekstrovert akan cenderung menghindari suasana yang sedikit melibatkan orang atau bahkan tidak melibatkan orang sama sekali. Sikap kompetitif mereka yang membumbung, mendukung mereka untuk lebih mencairkan diri dalam lingkup lingkungan belajar. Perilaku mereka yang seperti itu pula dapat mendukung diri sendiri untuk mendapatkan apa yang telah menjadi keinginannya.

Sikap siswa kelas VII G dengan kepribadian ekstrovert memang lebih menyukai kompetisi dalam belajar, akan tetapi mereka tidak pernah bersikap acuh pada orang lain yang belum bisa memahami materi pembelajaran dengan baik. Setelah jam pelajaran usai, mereka akan mengulas lagi dengan kelompok masing-masing tentang materi bagian mana yang belum mereka kuasai dan pahami dengan baik. Sehingga dengan demikian, pemahaman dalam mempelajari sesuatu dari materi pembelajaran tersebut dapat diterima secara merata dengan baik.

Komunikasi sosial dengan teman sekelas terjalin dengan bagus, sebab upaya mereka menyelesaikan konflik antar sesama dilakukan dengan cara mediasi. Ketua kelas akan menjadi mereka di antara mereka. Sehingga kesalah pahaman yang terjadi sebelumnya dapat terselesaikan dengan baik. Para siswa kelas VII G dengan kepribadian ekstrovert akan mendukung teman mereka yang kurang dalam percaya diri. Misalkan, ketika presentasi sedang berlangsung, mereka membantu kawan yang bertugas untuk mempresentasikan hasil diskusi mereka di depan kelas, dengan cara menulis 
pokok pikiran dari hasil diskusi tersebut pada selembar kertas. Dengan demikian etentitas situasi sosial terjalin.

Psikologi Sosial memiliki ketertarikan dengan cakupan yang luas. Walapun demikian, fokus utama psikologi sosial adalah pada pemahaman mengenai bagaimana dan mengapa individu berperilaku, berpikir, dan memiliki perasaan tertentu dalam konteks situasi sosial. Yang dimaksud dengan situasi sosial adalah kehadiran orang lain secara nyata maupun secara imajinasi. ${ }^{23}$ Dalam situasi sosial siswa kelas VII $G$ dengan kepribadian ekstrovert lebih unggul jika akan memulai sebuah topik percakapan atau pun memimpin sebuah diskusi. Peran mereka terlihat menonjol dan mendominasi, sehingga dalam pembelajaran pula mereka dapat melakukan sebuah interaksi sosial. Dengan adanya interaksi tersebut masing-masing siswa akan memiliki reaksi tersendiri pada diri mereka terhadap lingkungan yang sedang berkomunikasi dengan mereka. Karena kepribadian ekstrovert lebih membuka diri, kebanyakan dari harapan mereka terpenuhi. Dalam artian, ia dapat atau bisa menyampaikan isi pikiran dan pendapat yang ia miliki. Sangat mudah pula dalam mengantongi peluang untuk menjadi yang terbaik di mata orang lain. Selain berkomunikasi, mereka dengan mudah memahami apa yang harus dia lakukan ketika sesuatu mendesak mereka untuk menyelesaikannya dengan tepat.

Berdasarkan pengamatan yang dilakukan oleh peneliti, siswa kelas VII $\mathrm{G}$ dengan kepribadian introvert atau pendiam mereka cenderung lebih menyelundupkan diri. Dalam artian lebih memilih bekerja di balik layar, atau hanya dengan menyumbangkan gagasan dari pemikiran mereka. Meskipun tidak terlihat menonjol seperti para kepribadian terbuka, siswa dengan kepribadian introvert memiliki lebih banyak kemampuan berpikir di suasana tenang. Mereka menyukai kesendirian, dan menyukai katenangan, bukan berarti tidak mau berteman atau sangat menutup diri pada lingkungan. Akan tetapi, perasaan mereka akan lebih senang jika berada pada suasana tenang.

Siswa introvert memilih menyimpan pendapatnya sebab kepercayaan diri mereka berkurang ketika salah seorang dari temannya menyampaikan

${ }^{23}$ Robert A. Baron, Donn Byrne, Psikologi Sosial (Ciracas, Jakarta: Penerbit Erlangga, 2004) 5 
pendapat lebih bagus. Saat tanya jawab dilaksanakan oleh guru mata pelajaran, ia akan lebih sering menutup mulut. Jika guru tidak menunjuknya mengajukan pendapat yang ia punya, maka dia tidak akan membuka suara. Namun, pada waktu guru membentuk sebuah kelompok diskusi, mereka akan berpendapat dengan baik. Membandingkan hasil pemikiran yang dia punya dengan milik orang lain, mencari bahan materi untuk di presentasikan nantinya.

Meskipun tidak terlalu menyukai tampil di depan publik, justru cara kerja para siswa tertutup ini sangat memperhatikan kesempurnaan jawaban yang telah di diskusikan sebelumnya. Ketelitian mereka sangat baik, dengan begitu pekerjaan kelompok yang telah di berikan oleh guru terselesaikan tepat waktu. Dalam segi pemahaman, setiap orang memiliki tingkat kepahaman yang berbeda, sehingga walaupun para siswa pendiam tersebut tidak lebih cepat memahami sebuah materi, mereka tetap bisa memahami dari penjelasan tambahan teman sebaya mereka. Dukungan lingkungan, dapat mendorong kepercayaan diri mereka dengan sangat baik.

Menyangkut berinteraksi, introvert sering kali tidak terlalu mendominasi segala hal. akan tetapi mereka dapat dengan mudah dan nyaman ketika sedang berbicara dengan sebaya atau pun berkomunikasi dengan seseorang yang lebih tua dari pada mereka. Siswa introvert memang tidak terlalu banyak bicara, namun mereka memiliki sesuatu yang akan mengejutkan orang lain, dalam artian mereka berusaha menghindari hal yang merugikan dirinya. Dengan cara tidak bertindak gegabah dalam melakukan sesuatu untuk di tampilkan pada publik.

Hall dan Lidzey menjelaskan bahwa karakteristik dari sifat introvert cenderung pemalu, introspektif, menyukai buku atau kutu buku, tidak terlalu ramah kecuali pada seseorang yang dikenal atau teman dekatnya, mereka juga cenderung merencanakan sesuatu dengan berhati-hati sebelum melakukan sesuatu atau mengambil langkah mengaplikasikan sesuatu. Dan tidak mudah percaya pada kata hati atau kurang percaya diri. Mereka menanggapi permasalahn secara serius, menyukai keteraturan, mereka pula selalu 
menyembunyikan perasaan, jarang bertingkah agresif dan tidak mudah kehilangan kesabaran. ${ }^{24}$

Secara garis besar, memang para introvert tidak terlalu banyak atau pun terlihat melakukan interaksi pada banyak orang. Akan tetapi, ia memiliki keunikan dalam menjalin komunikasi dengan lingkungan sosial. Dia cenderung lebih menunggu seseorang memulai sebuah percakapan atau menyematkan sebuah topik percakapan. Mereka hanya melihat reaksi-reaksi orang lain terhadap kehadiran dirinya di dalam lingkungan tersebut. Jadi itulah mengapa, banyak dari mereka memiliki sifat pemalu.Kebanyakan dari pemilik sifat introvert memilih lebih mendengarkan perasaan atau batin pada dirinya, meskipun tidak banyak interaksi yang dia ciptakan pada lingkungan. Dia sangat baik jika seseorang mengajaknya untuk berkomunikasi. Kebanyakan dari pribadi introvert berfokus pada diri mereka sendiri lebih dulu kemudian melepaskannya pada orang lain. dalam artian, mereka tidak terlalu suka mencari perhatian atu diperhatikan oleh lingkungan sosial yang sedang dia tempati.

Begitu pula dengan siswa kelas VII G dengan kepribadian tertutup atau introvert akan lebih membanggakan diri jika seseorang mempercayainya melakukan sesuatu demi kepentingan bersama. Sebab, ia merasa mendapatkan dorongan dari lingkungan sekitar. Memang mereka tidak cukup unggul dalam hal kepercayaan diri pada lingkup di depan banyak orang. Akan tetapi, dia akan sangat luar biasa ketika mendapat dukungan dari lingkungan sekitar.Pada dasarnya, kedua kepribadian tersebut saling keterkaitan, hal ini juga atas jasa dari para guru yang telah menciptakan suasana menyenangkan. Membuat kelompok diskusi untuk kenyamanan para anggota kelas, membentuk berbagai kuis bermanfaat dan menyenangkan, menciptakan stimulus seimbang bagi para siswa dengan keragaman kepribadian tersebut. Sebab itu pula, para siswa dapat saling membantu ketila sedang dalam pembelajaran. Dengan demikian belajar juga menjadi pembelajaran bagi mereka untuk saling berinteraksi dengan baik. Sehingga kecanggungan tidak akan tercipta, dan hubungan antara guru dengan siswa dapat terjalin baik.

${ }^{24}$ Viola Dena Halifah, "Hubungan Antara Kepribadian Ekstrovert-Introvert dan Kecenderungan Implusive Buying Remaja Putri Pada Produk Fashion”, skripsi, Program Studi Psikologi Fakultas Psikologi, Universitas Sanata Dharma Yoyakarta, 2019 


\section{Kepribadian Ekstrovert Dan Introvert Pada Siswa Kelas VII G SMP Negeri 2 Ponorogo Pada Proses Pembelajaran Dalam Prespektif Psikologi Sosial}

Secara psikologis, manusia merupakan individu yang unik. Dengan demikian, siswa juga memiliki keunikan tersendiri pada setiap individu, baik ditinjau dari segi tingkat kecerdasan, kemampuan, sikap, motivasi, perasaan serta karakteristik-karakteristik lainnya. Psikologi sosial dalam kaitannya dengan pengembangan interaksi dan komunikasi dalam pembelajaran, dengan pemahaman aspek-aspek perilaku dalam konteks belajar mengajar. Pada intinya memberikan perhatian terhadap bagaiamana in put, proses dan out put pendidikan dan pembelajaran IPS dapat berjalan dengan tidak mengabaikan aspek perilaku dan kepribadian peserta didik.

Dengan demikian Psikologi sosial merupakan salah satu aspek pendukung dalam pembelajaran IPS terhadap perkembangan peserta didik dalam mengikuti pembelajaran di dalam kelas. Sehingga dengan harapan komunikasi dan interaksi dapat terjalin dengan baik antara sesama siswa maupun dengan pengajar. Kemudian tujuan pembelajaran IPS dapat terpenuhi dan tersampaiakan dengan sepenuhnya.

\section{PENUTUP}

Berdasarkan penelitian yang dilakukan oleh peneliti di SMP Negeri 2 Ponorogo mengenai Kepribadian Ekstovert dan Introvert Pada Siswa Kelas VII G Pada Proses Pembelajaran dalam prespektif Psikologi Sosial, bahwa terdapat interaksi antara model pembelajaran yang diterapkan dengan tipe kepribadian pada saat pembelajaran IPS di dalam kelas. Lebih jauh dapat dilihat bahwa apabila dalam pelaksanaan pembelajaran IPS siswa di dalam kelas menurut tipe kepribadian, maka ditemukan bahwa model pembelajaran berbasis ceramah guru di depan kelas memberikan respon yang berlawanan. Bagi kelompok siswa yang memiliki kepribadian introvert lebih baik daripada ketika sedang menggunakan metode pembelajaran tanya jawab. Sedangkan bagi kelompok siswa dengan kepribadian ekstrovert mereka tidak lebih baik dengan metode pembelajaran ini, akan tetapi beberapa dari mereka dapat menyesuaikan diri sehingga pembelajaran berjalan baik. Sehingga guru sesekali menggunakan metode diskusi sebagai implus bagi siswa agar pembelajaran IPS berjalan menyenangkan, serta komunikasi dan interaksi antara sesama dapat terjalin baik.

Pada dasarnya, terganggunya tujuan pembelajaran IPS di dalam kelas di klasifikasikan menurut tipe kepribadian. Maka siswa dengan kepribadian 
introvert kurang bisa menanggapi dengan cepat pertanyaan dan perintah dari guru sehingga fokus guru hanya tertuju pada siswa tersebut. Sedangkan siswa dengan kepribadian ekstrovert tidak memperhatikan pembelajaran dengan baik ketika sudah merasa bosan.

Berdasarkan uraian di atas, kesimpulan dalam penelitian ini adalah bahwa terganggunya tujuan pembelajaran disebabkan oleh faktor internal siswa sehingga guru memberikan implus agar pembelajaran tetap berjalan baik. Dengan menggunakan metode diskusi pula siswa dengan dua kepribadian berbeda tersebut dapat melakukan pembelajaran dengan baik serta dapat berinteraksi sesuai dengan prespektif psikologi sosial.

\section{DAFTAR PUSTAKA}

Alwisol. (2014). Psikologi Kepribadian. Malang: UMM Press

Chain,Susan. (2013) Quiet, Kekuatan Introver di dalam Dunia yang Tidak Bisa Berhenti Bicara. Yogyakarta: ANDI.

Fadilaturrahmi. (2018). Lingkungan Belajar Efektif Bagi Siswa Sekolah Dasar. Basicedu. Fajar kurniawan, Mohamad. (2016) Perilaku Pro-Sosial Ditinjau Dari Tipe Kepribadian Introvert Dan Ekstrovert. Studi Pada Mahasisa Jurusan Psikologi Fakultas Ilmu Pendidikan Universitas Negeri Semarang.

Fakhrurrazi. (2018) Hakikat Pembelajaran Yang Efektif. Jurnal At-tafkir, Vol. 11 (2).

Halifah, Viola Dena. (2019). Hubungan Antara Kepribadian Ekstrovert-Introvert dan Kecenderungan Implusive Buying Remaja Putri Pada Produk Fashion. Program Studi Psikologi Fakultas Psikologi, Universitas Sanata Dharma Yoyakarta.

Hardani, dkk. (2020) Metode Penelitian Kualitatif dan Kuantitatif. Yogyakarta; Pustaka Ilmu.

Komang Sri Widiantari, dkk. Perbedaan Intensitas Komunikasi Melalui Jejaring Sosial Antara Tipe Kepribadian Ekstrovert Dan Introvert Pada Remaja. Jurnal Psikologi Udayana, Vol. 1, No. 1

Moleong, Lexy J. (2017) Metodologi Penelitian Kualitatif (P. 248) Bandung; PT. Remaja Rosdakarya

Rakhmat,Jalaluddin. (2018). Psikologi Komunikasi (p.18) Bandung: Simbiosa Rekatama Media.

Robert, dkk. (2004). Psikologi Sosial (P.5) Ciracas, Jakarta: Penerbit Erlangga.

Santi, Unika Prihat Menggunakan Studi Kasus sebagai Metode Ilmiah Dalam Psikologi. Buletin Psikologi.

Silvia, (2018). Hubungan Antara Ilmu-ilmu Sosial dan IPS. Ijtimaiyah, Vol. 2,( 1), 3 


\section{Kepribadian Ekstrovert Dan Introvert Pada Siswa Kelas VII G SMP Negeri 2 Ponorogo Pada Proses Pembelajaran Dalam Prespektif Psikologi Sosial}

Sinuraya, Dony. (2009). Hubungan Antara Kepribadian Ekstrovert dengan perilaku Agresi Pada RemajaFakultas Psikologi, Universitas Muhammadiyah Surakarta.

Sugiyono, (2015). Metode Penelitian Pendidikan Pendekatan Kuantatif, Kualitatif, dan $R \& D$.. Bandung:Alfa Beta.

Suryabrata, Sumadi. (2016). Psikologi Kepribadian, (p.185)Jakarta: PT Rajagrafindo Persada

Wahidmurni, (2014). Pemapamaran Metode Kualitatif, Dosen Fakultas Tarbiyah dan Keguruan, UIN Maulana Malik Ibrahim Malang.

Wiji Lestari, Sri. (2016). Analisis proses berpikir kritis siswa dalam pemecahan masalah matematika pada pokok bahasan himpunan ditinjau dari tipe kepribadian ekstrovert dan introvert siswa kelas VII SMPN 2 Sumber Cirebon. Jurusan Ilmu Pendidikan Matematika, UIN Walisongo Semarang.

Wilcox, Lynn. (2018). Psikologi Kepribadian.Banguntapan Yogyakarta: Ircisod.

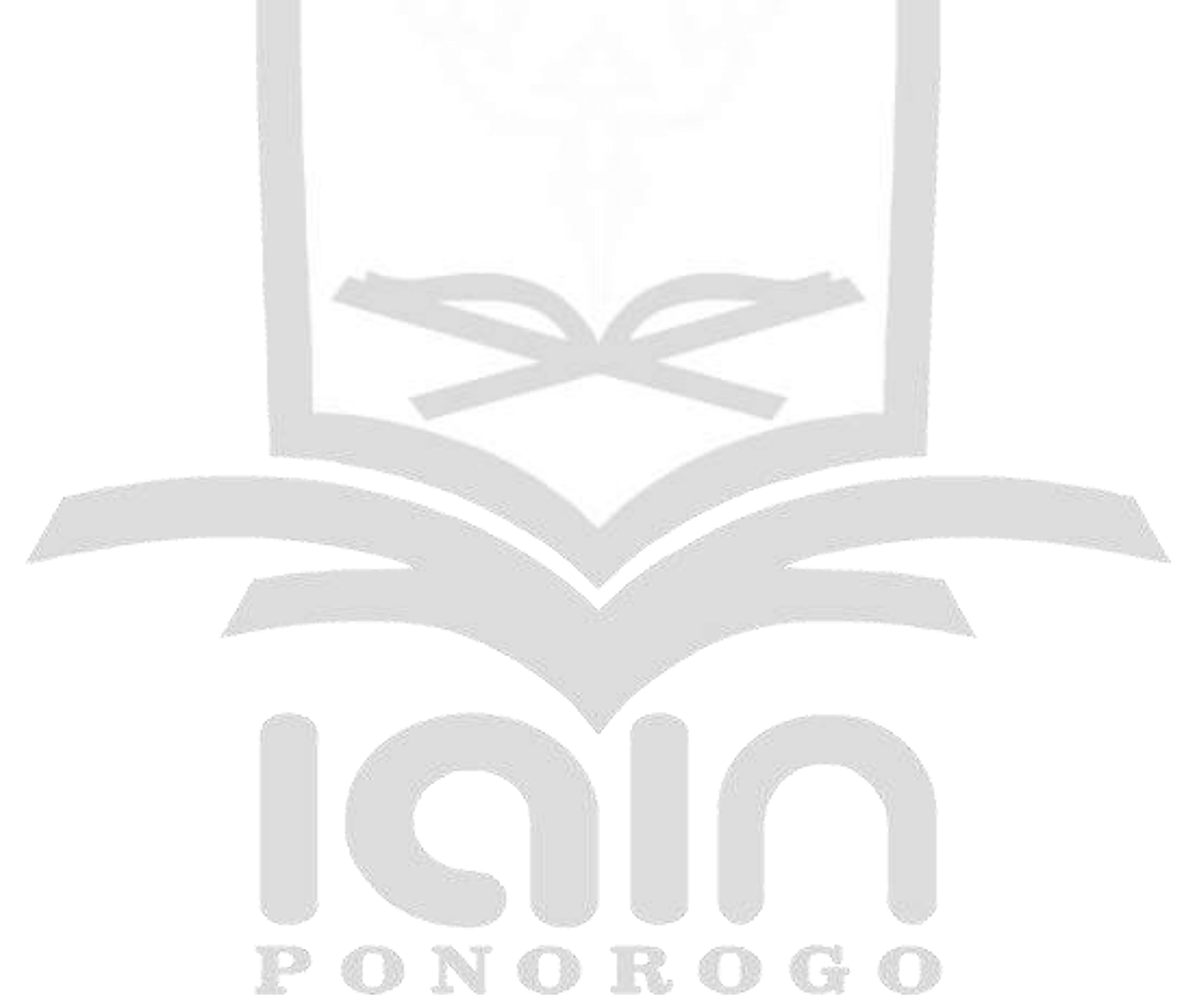

